\title{
PERILAKU OVERCONFIDENCE DI BURSA EFEK INDONESIA (BEI) (Studi kasus pada Index LQ45 periode 2014-2016)
}

\author{
Indri Hartiyaningsih \\ Jurusan Manajemen STIE Bank BPD Jateng \\ Email: indrihartiyan002@gmail.com \\ Yanuar Rachmansyah \\ Jurusan Manajemen STIE Bank BPD Jateng \\ Email: yanuarrachmansyah@stiebankbpdjateng.ac.id
}

Received: May 2018; Accepted: June 2018; Available online: July 2018

\begin{abstract}
Abstrak
Penelitian ini bertujuan untuk mengidentifikasi perilaku overconfidence investor di Bursa Efek Indonesia dari tahun 2014 hingga 2016. Overconfidence adalah bias psikologis yang dapat menyebabkan investor melakukan perdagangan yang berlebihan sebagai efek dari keyakinan bahwa mereka memiliki pengetahuan khusus yang sebenarnya tidak mereka miliki dan membuat investor overstimate (overestimating) kemampuannya untuk mengevaluasi investasi. Pendekatan untuk melihat perilaku overconfidence adalah dengan melihat pola hubungan antara return saham, volatilitas saham, dan volume transaksi.

Dalam penelitian ini digunakan Vector Autoregression (VAR). Data yang digunakan dalam penelitian ini adalah return saham, volatilitas saham dan volume transaksi bulanan. Sampel yang digunakan adalah perusahaan yang secara konsisten memasukkan Indeks LQ45 periode 2014 hingga 2016. Analisis VAR menggunakan beberapa metode untuk menjawab masalah penelitian yaitu estimasi model VAR dan Impulse Response Function. Dari hasil pengujian menggunakan analisis VAR, menunjukkan bahwa investor Indonesia mengalami overconfidence. Hasil estimasi Vector Autoregression menunjukkan bahwa hubungan antara return dan volume perdagangan tidak signifikan, tetapi memberikan kontribusi positif berdasarkan nilai koefisien. Sementara hubungan antara volatilitas dengan volume perdagangan menunjukkan hasil positif yang signifikan.
\end{abstract}

Kata kunci: Overconfidence, Return Saham, Volume Perdagangan, Volatilitas, Vector Autoregression (VAR), Fungsi Respon Impuls

\begin{abstract}
This study purposed to identify overconfidence behavior investor in Indonesia Stock Exchange from 2014 until 2016. Overconfidence is a psychological bias that can cause investors to excessive trading as the effect of the belief that they have specific knowledge they do not actually have and making the overstimate investor (overestimating) his ability to evaluate an investment. Approach to see the behavior of overconfidence is to see the pattern of relationship between stock returns, stock volatility and transaction volume.

In this study using the Vector Autoregression (VAR). The data used in this study are the stock return, volatility of the stock and the volume of monthly transactions. The samples used are companies that consistently enter Index LQ45 period 2014 until 2016. VAR analysis uses several methods to answer the research problem that is estimation of VAR model and Impulse Response Function. From the test results using VAR analysis, show that Indonesian investors experience overconfidence. The result of Vector Autoregression estimation shows that the relationship between return and trade volume is not significant, but gives positive contribution based on coefficient value. While the relationship between volatility with trade volume showed a significant positive result.
\end{abstract}

Keywords: Overconfidence, Stock Return, Trading Volume, Volatility, Vector Autoregression (VAR), Impulse response function

How to Cite: Hartiyaningsih, I., \& Rachmansyah, Y. (2018). Perilaku Overconfidence Di Bursa Efek Indonesia (BEI) (Studi kasus pada Index LQ45 periode 2014-2016). Media Ekonomi dan Manajemen, 33(2), 214-230. 


\section{PENDAHULUAN}

Pasar modal merupakan komponen penting dalam perekonomian sebuah negara. Banyak perusahaan yang memanfaatkan pasar modal untuk menyerap investasi sebagai upaya memperkuat posisi keuangannya. Pasar modal adalah pertemuan antara pihak yang kelebihan dana dengan pihak yang membutuhkan dana dengan cara memperjual belikan sekuritas (Tandellin 2010: 26). Pihak yang membutuhkan dana adalah perusahaan yang menjual saham sedangkan pihak yang kelebihan dana adalah masyarakat atau investor yang akan menanamkan dananya pada perusahaan yang mereka inginkan dengan membeli saham. Dalam rangka melaksanakan kegiatan investasi tersebut, investor perlu mengambil keputusan investasi. Keputusan investasi seorang investor selama ini dilihat dari dua sisi, yaitu : faktor ekonomi yang membahas sejauh mana keputusan tersebut dapat memaksimalkan kekayaan dan behavioral motivation atau motivasi dalam perilaku yang menjelaskan tentang keputusan investasi berdasarkan aspek psikologis investor (Christiani dan Mahastanti, 2011).

Dalam literatur keuangan ada suatu asumsi kuat mengenai pasar modal yang telah dibangun sejak lama yaitu tentang hipotesis pasar efisien (efficiency market hypotesis). Menurut fama (1970) dalam Jogiyanto (2014:597) suatu pasar dikatakan efisien jika harga-harga sekuritas mencerminkan secara penuh informasi yang tersedia (a security of market is efficient if security prices fully reflect the information available). Atinya harga saham akan merefleksikan seluruh informasi yang ada pada saat itu, sehingga investor percaya bahwa harga tersebut adalah harga yang fair. Secara keseluruhan hipotesis pasar efisien telah menjadi dasar teori keuangan standar yang menjelaskan bahwa pelaku pasar memiliki perilaku yang rasional. Pada dasarnya investor rasional akan memaksimalkan utilitasnya (imbal hasil dan risiko) berdasarkan informasi yang tersedia di pasar. Akan tetapi teori tersebut tidak dapat memberikan penjelasan adanya anomalianomali di pasar modal seperti jauary effect, size effect dan sebagainya.

Dewasa ini perilaku investor sudah tidak sepenuhnya dijelaskan oleh teori keuangan standar. Dalam kenyataannya investor dalam melakukan investasi tidak hanya mempertimbangkan estimasi dari prospek investasinya namun ada faktor psikologi yang mempengaruhi dalam keputusan investasi. Fakta yang ada menunjukan bahwa sejak tahun 1990-an semakin banyak penelitian yang menemukan ketidakefisienan pasar. Semakin banyak penelitian yang membuktikan bahwa aspek perilaku ikut berperan dalam pembentukan harga di pasar modal. Sejak saat itulah mulai berkembang behavioral finance yang membahas sejauh mana aspek psikologi berpengaruh dalam pengambilan keputusan investasi (Asri Marwan, 2013:202-203).

Behavioral finance secara umum didefinisikan sebagai aplikasi psikologi dalam keuangan (Pompian, 2006:4). Behavioral finance merupakan pendekatan yang menjelaskan bagaimana manusia melakukan investasi yang dipengaruhi oleh faktor psikologi. Behavioral finance dibagi menjadi dua topik yaitu behavioral finance macro yang mendeskripsikan anomalianomali dalam hipotesis pasar efisien yang mungkin dapat dijelaskan dengan model behavioral (keperilakuan) dan bahavioral finance micro yang menguji perilakuperilaku atau bias-bias psikologis dari investor individual yang membedakannya dari perilaku rasional yang dikemukakan oleh teori ekonomi klasik, teori portofolio dan hipotesis pasar efisien (Pompian, 2006:9). Ada beberapa jenis psikologi yang menyebabkan pada saat kondisi tertentu investor bertidak tidak rasional. Salah satu perilaku tidak rasional investor adalah perilaku overconfidence.

Overconfidence adalah perasaan percaya diri yang berlebih. Overconfidence menyebabkan orang overestimate terhadap 
pengetahuan yang dimiliki dan understimate terhadap risiko dan melebihlebihkan kemampuan yang dimiliki dalam hal melakukan kontrol atas apa yang terjadi (Nofsinger, 2005:10). Perilaku overconfidence mencerminkan perilaku manusia yang irasional karena proses pengambilan keputusan tidak dilakukan berdasarkan prinsip-prinsip rasionalitas normatif yang mengacu pada expected utility tertinggi (Asri Marwan, 2013:147)

Overconfidence membuat investor cenderung mengikuti strategi perdagangan pada masa lalu dengan harapan akan mendapatkan gain yang sama di masa akan datang (Griffin, Haris dan Topaloglu, 2003). Overconfidence membuat pasar menjadi tidak seimbang dan bergerak dengan pola yang sulit diprediksi. Perubahan pola tersebut terutama akan mempengaruhi pola hubungan antara return, volume perdagangan dan volatilitas. Menurut Gervais dan Odean (2001) return masa lalu yang diperoleh investor dapat digunakan untuk mengidentifikasi perilaku overconfidence investor di pasar keuangan.

Return digunakan untuk mengidentifikasi apakah investor melakukan perdagangan lagi atau tidak. Jika investor memperoleh return tinggi, maka dia akan meningkatkan volume perdagangan dimasa depan. Sebaliknya jika investor memperoleh return yang rendah, mereka tidak akan melakukan perdagangan sehingga volume perdagangan menurun. Hal serupa juga di kemukakan oleh Statman dan Theorly (2006) yang melakukan pengujian tentang overconfidence, dia menyatakan bahwa tingkat overconfidence berubah bersama return sehingga return dapat digunakan untuk mengidentifikasi perilaku overconfidence. Investor akan lebih overconfidence setelah mendapatkan return yang positif dan menurun setelah mendapatkan return yang negatif. Berdasarkan pernyataan diatas dapat disimpulkan bahwa return yang tinggi akan membuat investor overconfidence dan akan menaikan volume perdagangannya dengan harapan akan mendapatkan keuntungan yang sama di masa mendatang.

Hubungan antara volatilitas dengan volume perdagangan dapat dijelaskan melalui Teori Prospek yang dikemukakan oleh Kehneman dan Tversky (1979). Teori ini menyatakan bahwa seseorang dalam kondisi ketidakpastian, orang akan memilih pilihan yang menghasilkan expected utility terbesar. Teori ini juga mengungkapkan adanya ketidakkonsistenan perilaku manusia terhadap risiko demi mendapatkan keuntungan dan perilakunya ketika menghadapi risiko keugian (asymetry of human choices) (Asri Marwan, 2013:234). Dari teori tersebut dapat disimpulkan bahwa dalam kondisi pasar normal, ketika tingkat risiko (volatilitas) naik maka investor akan cenderung menghindari risiko kerugian dengan mengurangi transaksinya, sehingga volume perdagangan menurun.

Akan tetapi pasar modal indonesia menunjukan fenomena yang berbeda seperti grafik di Gambar 1.

Hubungan antara return dan volume perdagangan ditemukan fenomena menarik dimana ketika return turun volume perdagangan meningkat. Hal tersebut terlihat pada saham BBCA dan AKRA. Pada bulan Februari sampai April 2015 saham BBCA ketika return menurun dari 0.0542, 0.0514 menjadi -0.0911 pada bulan April volume perdagangan justru meningkat menjadi dari 230.571.500, 304.450 .300 sampai 413.703 .700 lebih tinggi dari bulan sebelumnya. Hal yang sama juga terjadi pada saham AKRA yaitu dimana return menurun dari bulan Juni sampai Agustus 2015 sebesar 0.0821918 menjadi -0.029536 dan -0.004348 tetapi volume perdagangan justru meningkat dari 108.511.200, 140.977.800 dan menjadi 189.376.000. Ketika return turun investor cenderung lebih agresif menjual beli saham yang mengakibatkan volume perdagangan meningkat. Sebaliknya ketika return saham meningkat investor cenderung menahan pembelian sehingga volume perdagangan menurun, seperti yang terlihat pada saham 
AKRA pada bulan november dan desember 2015 misalnya return saham meningkat dari 0.0338983 menjadi 0.1762295 . Volume perdagangan justru menurun dari 323.279.100 menjadi 141.199.300

Selanjutnya hubungan antara volatilitas dan volume perdagangan tidak sesuai dengan teori prospek. Sebagai contoh pada saham AKRA dibulan Januari-Maret 2016, volatilitas (tingkat risiko) naik dari $0.0158,0.0164$ menjadi 0.271 yang diikuti dengan kenaikan volume perdagangan dari 94.932.800, 115.246.600 dan 161.164.800 dan pada saham BBCA ketika volatilitas naik dari 0.002 menjadi 0.005 dan 0.049 volume perdagangan juga mengalami kenaikan sebesar 216.387.400, 320.311.200 dan 364.043.300 pada Mei-Juli 2016. Fenomena tersebut menunjukan pasar modal tidak efisien. Hal tersebut juga didukung oleh penelitian Sindhu dan Waris (2014) yang menyatakan bahwa return berhubungan positif dengan volatilias dan volume perdaganga. Hasil penelitian tersebut juga didukung oleh penelitian Salma Zaiane (2013) dimana volatilitas berhubungan positif dengan volume perdagangan.
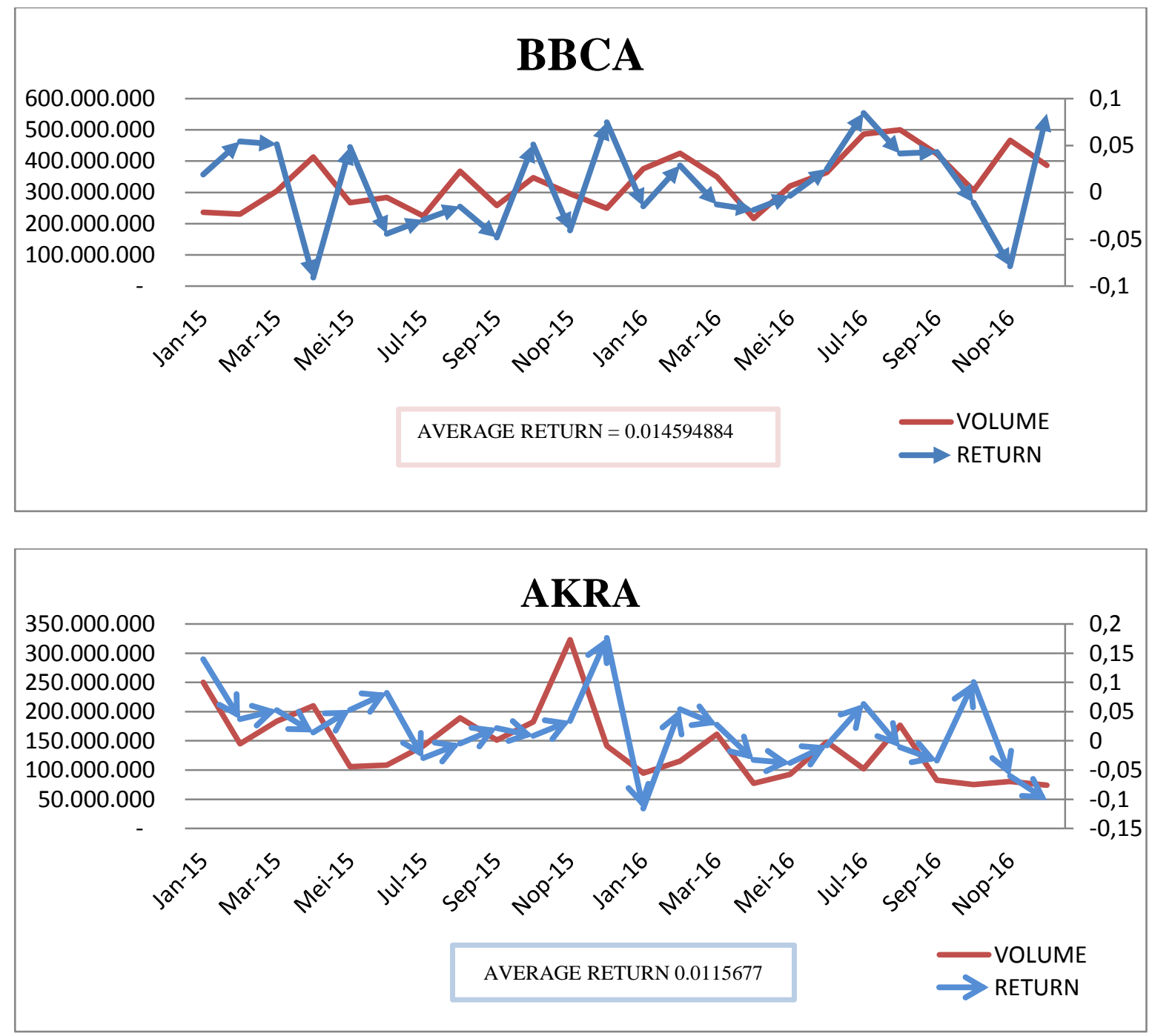

Gambar 1. Fenomena Yang Berbeda Pasar Modal Indonesia 


\section{KAJIAN PUSTAKA}

\section{Teori Pasar Modal}

Pasar modal mempunyai peranan penting bagi perekonomian suatu negara. Pasar modal adalah pertemuan antara pihak yang kelebihan dana dengan pihak yang membutuhkan dana dengan cara memperjual belikan sekuritas (Tandellin 2010: 26). Pihak yang membutuhkan dana adalah perusahaan yang menjual saham sedangkan pihak yang kelebihan dana adalah masyarakat atau investor yang akan menanamkan dananya pada perusahaan yang mereka inginkan dengan membeli saham. Pasar modal menurut UndangUndang Pasar Modal Pasal 1 No.8 tahun 1995 merupakan kegiatan yang bersangkutan dengan penawaran umum dan perdagangan efek, perusahaan publik yang berkaitan dengan efek yang diterbitkannya, serta lembaga dan profesi yang berkaitan dengn efek. Sedangkan menurut Keputusan Menteri Keuangan RI No.1548/KMK/1990 dalam Sunariyah (2011) pasar modal adalah suatu sistem keuangan yang terorganisasi, termasuk didalamnya adalah bank-bank komersial dan semua lembaga perantara dibidang keuangan, serta keseluruhan surat berharga yang beredar.

Jenis-jenis pasar modal menurut sunariyah (2011:12-15) adalah :

1. Pasar Perdana (Primary Market) Pasar perdana adalah penawaran saham dari perusahaan yang menerbitkan saham (emiten) kepada pemodal selama waktu yang ditetapkan oleh pihak sebelum saham tersebut diperdagangkan di pasar sekunder.

2. Pasar Sekunder (Secondary Market) Pasar sekunder merupakan pasar dimana saham dan sekuritas diperjualbelikan secara luas setelah melalui masa penjualan di pasar perdana. harga saham di pasar sekunder ditentukan oleh permintaan dan penawaran antara pembeli dan penjual.
3. Pasar Ketiga (Third Market)

Pasar ketiga merupakan tempat perdagangan saham atau sekuritas lain di luar bursa (over the counter market).

4. Pasar Keempat (Fourth Market)

Pasar keempat merupakan bentuk perdagangan efek antar pemodal atau dengan kata lain pengalihan saham dari satu pemegang saham ke pemegang lainnya tanpa melalui perantara pedagang efek.

\section{Investasi}

Investasi merupakan penanaman modal untuk satu atau lebih aktiva yang dimiliki dan biasanya berjangka waktu lama dengan harapan mendapatkan keuntungan dimasa akan datang (Sunariyah,2011:4). Keputusan penanaman modal dapat dilakukan oleh individu maupun sutu entitas yang mempunyai kelebihan dana. Dari pengertian tersebut dapat disimpulakan bahwa investasi merupakan penyaluran sumber dana sekarang dengan menempatkan dana pada suatu emiten berupa pembelian efek berupa saham dengan harapan mendapat keuntungan dimasa akan datang.

Menurut Sunariyah (2011:4) Investasi dibagi menjadi dua yaitu :

1. Investasi Dalam Bentuk Aktiva Riil (Real Assets)

Aktiva riil merupakan aktiva berwujud seperti emas, perak, intan, barangbarang seni dan real estate

2. Investasi dalam Bentuk Surat-Surat Berharga (Marketable Securities atau Financial Assets)

Aktiva financial adalah surat-surat berharga yang pada dasarnya merupakan klain atas aktiva riil yang dikuasai oleh suatu entitas. Investasi pada aset keuangandapat dilakukan dengan dua cara yaitu :

- Investasi langsung

- Investasi tidak langsung 


\section{Hipotesis Pasar Efisien (Efficienct Market Hypotesis)}

Hipotesis Pasar Efisien (Efficient Market Hypothesis) pertama kali dikemukakan oleh Eugene Fama. Menurut Fama (1990) dalam Jogiyanto (2014) suatu pasar sekuritas dikatakan efisien jika harga-harga sekuritas mencerminkan secara penuh informasi yang tersedia (a security market in efficient if security prices fully reflect the information available). Fama (1970) membagi tiga macam bentuk utama dari pasar efisien berdasarkan informasi yang tersedia di pasar, yaitu :

1. Efisiensi Pasar Bentuk Lemah (Weak Form)

Pasar dikatakan efisien dalam bentuk lemah jika harga-harga dari sekuritas mencerminkan secara penuh (fully reflect) informasi masa lalu. Informasi masa lalu merupakan informasi yang sudah terjadi. Bentuk efisiensi pasar secara lemah ini berkaitan dengan dengan teori langkah acak (random walk theory) yang menyatakan bahwa data masa lalu tidak berhubungan dengan nilai sekarang. Jika pasar efisien secara bentuk lemah, maka nilai-nilai masa lalu tidak dapat digunakan untuk memprediksi harga sekarang. Ini berarti bahwa untuk pasar yang efisien bentuk lemah, investor tidak dapat menggunkan informasi masa lalu untuk mendapatkan keuntungan yang tidak normal.

2. Efisiensi Pasar Bentuk Setengah Kuat (Semistong Form)

Pasar dikatakan efisien setengah kuat jika harga-harga sekuritas mencerminkan semua informasi (fully reflect) semua informasi yang dipublikasikan (all publicly available information) termasuk informasi yang berada di laporan-laporan keuangan perusahaan emiten.
3. Efisiensi Pasar Bentuk Kuat (Strong Form)

Pasar dikatakan efisien dalam bentuk kuat jika harga-harga sekuritas secara penuh mencerminkan (fully reflect) semua informasi yang tersedia termasuk informasi yang privat. Jika pasar efisien dalam bentuk ini, maka tidak ada investor yang dapat memperoleh keuntungan tidak normal (abnormal return) karena mempunyai informasi privat.

\section{Behavioral Finance}

Behavioral finance adalah studi tentang pengaruh psikologi pada perilaku investor dan efek berikutnya di pasar modal. Behavioral finance menarik karena membantu menjelaskan mengapa dan bagaimana mungkin pasar tidak efisien. Menurut Shefrin (2000) behavioral finance adalah studi yang mempelajari tentang bagaimana fenomena psikologi mempengaruhi tingkah laku keuangannya. Behavioral finance secara umum didefinisikan sebagai aplikasi psikologi dalam keuangan (Pompian,2006:4). Menurut Pompian (2006:9) behavioral finance dibagi menjadi dua yaitu :

1. Behavioral finance macro, yang mendeskripsikan anomali-anomali dalam hipotesis pasar efisien yang mungkin dapat dijelaskan dengan model behavioral (keperilakuan).

2. Behavioral finance micro, yang menguji perilaku-perilaku atau biasbias psikologis dari investor individual yang membedakannya dari perilaku rasional yang dikemukakan oleh teori ekonomi klasik, teori portofolio dan hipotesis pasar efisien.

Menurut Ricciardi (2000) behavioral finance merupakan suatu disiplin ilmu yang didalamnya melekat informasi berbagai disiplin ilmu (interdisipliner) dan terus menerus berintegrasi sehingga pembahasannya tidak bisa dilakukan isolasi. 


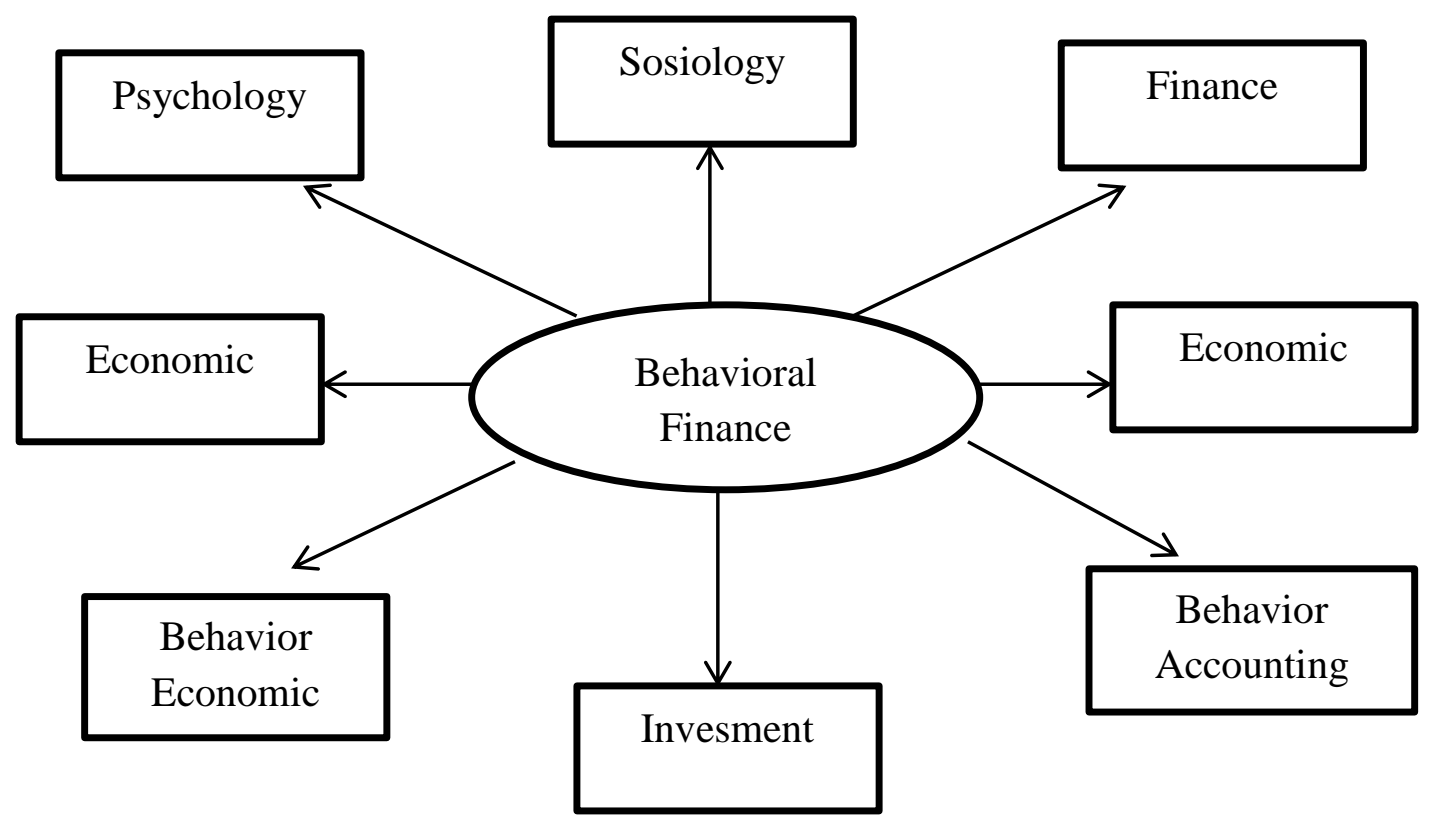

Sumber : Ricciardi (2005:10)

Gambar 2. Keterlibatan Behavioral Finance dengan berbagai disiplin ilmu

Gambar 2 memperlihatkan bahwa behavioral finance dipengaruhi oleh beberapa faktor yaitu sosiologi, keuangan, ekonomi, akuntansi dan psikologi. Hal tersebut menerangkan bahwa behavioral finance tidak semata-mata selalu bersifat rasional namun juga dipengaruhi oleh krtidakrasionalan yaitu seperti psikologi dan sosiologi.

\section{Overvonfidence}

Overconfidence adalah perasaan percaya diri yang berlebih. Overconfidence menyebabkan orang overestimate terhadap pengetahuan yang dimiliki dan understimate terhadap risiko dan melebihlebihkan kemampuan yang dimiliki dalam hal melakukan kontrol atas apa yang terjadi (Nofsinger, 2005 :10 dalam Nugroho dan Kartini 2015). Seorang yang overconfident akan merasa lebih pintar dan memiliki lebih banyak informasi (Pompian, 2006:51). Menurut (Pompian, 2006: 54) investor yang mengalami overconfidence akan mengalami kesalah investasi, diantaranya adalah :
1. Investor yang overconfidence menaksir secara berlebihan kemam- puan mereka untuk mengevaluasi perusahaan sebagai investasi yang potensial. Akibatnya, mereka bisa tidak memperhatikan informasi negatif yang biasanya mengindikasikan tanda peringatan bahwa pembelian saham tidak boleh dilakukan atau stok yang sudah dibeli harus dijual.

2. Investor yang overconfidence dapat melakukan perdagangan secara berlebihan sebagai akibat kepercayaan bahwa mereka memiliki pengetahuan khusus yang tidak dimiliki orang lain. Perilaku perdagangan yang berlebihan telah terbukti menghasilkan return yang buruk dari waktu ke waktu.

3. Karena mereka tidak tahu, tidak mengerti, atau tidak memperdulikan data statistik kinerja investasi historis, overconfidence investor dapat meremehkan risiko penurunan mereka. Akibatnya, dapat mengalami kinerja portofolio yang buruk.

4. Overconfidence investor memiliki portofolio yang kurang terwakili, sehingga mengambil risiko lebih besar tanpa perubahan risiko yang sepadan. Seringkali, overconfidence investor 
bahkan tidak tahu mereka menerima lebih banyak risiko daripada yang biasanya dapat mereka toleransi

Kesalahan-kesalahan yang biasanya muncul sebagai akibat adanya perilaku overconfidence dalam kaitannya dengan investasi dipasar keuangan menurut Pompian (2006:59-60) yaitu

1. Overconfidence dapat menyebabkan investor melakukan excessive trading (transaksi yang berlebihan) sebagai efek dari keyakinan bahwa mereka memiliki pengetahuan khusus yang sebenarnya mereka tidak miliki.

2. Overconfidence membuat investor overstimate (menaksir terlalu tinggi) kemampuannya dalam mengevaluasi suatu investasi.

3. Overconfidence menyebabkan investor understimate (menaksir terlalu rendah) terhadap risiko dan cenderung mengabaikan risiko.

4. Overconfidence menyebabkan investor memiliki kecenderungan tidak mendiversifikasi portofolio investasinya.

Perilaku overconfidence mencerminkan perilaku manusia yang irasional karena pengambilan keputusan tidak dilakukan bedasarkan prinsip-prinsip rasionalitas normatif yang mengacu pada expected utility tertinggi (Asri Marwan, 2013). Lichtensein dan Fischhoff (1997) mengatakan bahwa fenomena overconfidence merupakan kecenderungan pengambilan keputusan tanpa disadari untuk memberikan bobot penilaian yang berlebih pada pengetahuan dan akurasi informasi yang dimiliki serta mengabaikan informasi publik yang tersedia.

\section{Teori Prospek}

Teori Prospek dikemukakan oleh Kahneman dan Tversky (1979). Teori ini bertentangan dengan manfaat harapan yang banyak dipakai dalam menerangkan proses pengambilan keputusan. Teori prospek pada dasarnya adalah sebuah teori yang menyangkut keputusan yang akan diambil investor dengan melihat risiko (berkaitan dengan perilakunya terhadap risiko). Terori ini juga menjelaskan bagaimana investor menilai secara probabilistik berbagai outcomes (kejadian atau hasil) dengan memperhatikan risiko dan peluang masingmasing serta membuat keputusan berdasarkan nilai potensial kerugian (losses) dan keuntungan (gains).

\section{HIPOTESIS}

\section{Hubungan antara Return (Mret) dan Volume Perdagangan (Mturn)}

Return merupakan hasil yang diperoleh dari investasi terdiri dari capital gain (loss) dan yield. Sedangkan volume perdagangan merupakan jumalah lembar saham yang diperdagangkan secara harian (Jogiyanto, 2010). Volume perdagangan merupakan instrumen yang digunakan untuk melihat reaksi pasar modal terhadap informasi melalui parameter volume saham yang diperdagangkan di pasar (Sutrisno, 2000). Menurut Gervais dan Odean (2001) return masa lalu yang diperoleh investor dapat digunakan untuk mengidentifikasi perilaku overconfidence investor di pasar keuangan. Return digunakan untuk mengidentifikasi apakah investor melakukan perdagangan lagi atau tidak. Jika investor memperoleh return tinggi, maka dia akan meningkatkan volume perdagangan dimasa depan. Sebaliknya jika investor memperoleh return yang rendah, mereka tidak akan melakukan perdagangan sehingga volume perdagangan menurun.

Hal serupa juga di kemukakan oleh Statman dan Theorly (2006) yang melakuakan pengujian tentang overconfidence, dia menyatakan bahwa tingkat overconfidence berubah bersama return sehingga return dapat digunakan untuk mengidentifikasi perilaku overconfidence. Investor akan lebih overconfidence setelah mendapatkan return yang positif dan menurun setelah mendapatkan return yang negatif. Berdasarkan pernyataan diatas dapat disimpulkan bahwa return yang tinggi akan membuat investor overconfidence dan akan menaikan volume 
perdagangannya dengan harapan akan mendapatkan keuntungan yang sama di masa mendatang.

\section{H1 : Terdapat hubungan positif antara Return (Mret) dan Volume Perdagangan (Mturn)}

\section{Hubungan antara Volatilitas dengan Volume Perdagangan (Mturn)}

Hubungan antara volatilitas dengan volume perdagangan dapat dijelaskan melalui Teori Prospek yang dikemukakan oleh Kehneman dan Tversky (1979). Teori ini menyatakan bahwa seseorang dalam kondisi ketidakpastian, orang akan memilih pilihan yang menghasilkan expected utility terbesar. Teori ini juga mengungkapkan adanya ketidakkonsistenan perilaku manusia terhadap risiko demi mendapatkan keuntungan dan perilakunya ketika menghadapi risiko keugian (asymetry of human choices) (Asri Marwan, 2013:234). Dari teori tersebut dapat disimpulkan bahwa dalam kondisi normal, ketika tingkat risiko (volatilitas) meningkat maka investor cenderung akan mengurangi transaksinya terhadap suatu saham, sehingga volume perdagangan saham menurun.

Akan tetapi bias overconfidence menyebabkan investor understimate (menaksir terlalu rendah) terhadap risiko dan cenderung mengabaikan risiko serta tidak sepenuhnya mempertimbangkan kemungkinan timbulnya kerugian dalam portofolio mereka (Pompian, 2006: 60). Hal ini terjadi karena investor terlalu percaya diri pada penilaiannya sendiri dan memberikan bobot yang berlebih pada pengetahuan serta akurasi informasi yang dimiliki dengan mengabaikan informasi publik yang tersedia, sehinga membuatnya justru lebih agresif bertransaksi pada saham-saham yang lebih beresiko. Mereka memilih saham tersebut tanpa menganalisis ulang melalui analisis fundamental maupun teknikal melainkan hanya merujuk pada perolehan keuntungan besar yang mereka dapatkan pada transaksi sebelumnya. Hipotesis tersebut didukung oleh penelitin Shindu dan Waris (2014), Salma Zaiane (2013) yang hasil penelitiannya menunjukan bahwa volatilitas berhubungan positif dengan volume perdagangan saham.

\section{H2 : Terdapat hubungan positif antara Volatilitas dengan Volume Perdagangan (Mturn)}

\section{METODE PENELITIAN}

\section{Definisi Konsep}

Definisi konsep merupakan definisi secara konseptual yang diberikan pada setiap konsep (variabel konstruk) yang diajukan dalam penelitian, untuk memudahkan dalam memahami gambaran topik secara umum.Variabel yang digunakan dalam penelitian ini adalah Variabel Endogen yang terdiri dari Return dan Volume Perdagangan dan Variabel Eksogen yaitu Volatilitas.

\section{Definisi Operasional}

Untuk meneliti suatu konsep data secara empiris maka konsep tersebut harus dioperasionalkan dengan cara mengubahnya menjadi variabel yang mempunyai nilai. Penjelasan operasiona dari variabel-variabel dalam penelitian ini adalah seperti Tabel 1 . 
Tabel 2. Definisi Operasional Variabel

\begin{tabular}{|c|c|c|}
\hline Variabel & Devinisi & Operasionalisasi \\
\hline Return (Mret) & $\begin{array}{l}\text { Hasil yang diperoleh dari } \\
\text { investasi }\end{array}$ & $\begin{array}{l}\qquad R_{i t}=\frac{P_{t}-P_{t-1}}{P_{t-1}} \\
\mathrm{R}_{\mathrm{it}}: \text { Return saham perusahaan i pada } \\
\text { periode } \mathrm{t} \\
\mathrm{P}_{\mathrm{t}}: \text { Harga saham i pada periode } \mathrm{t} \\
\mathrm{P}_{\mathrm{t}-1}: \text { Harga saham i pada periode } \mathrm{t}-1\end{array}$ \\
\hline Volatilitas & $\begin{array}{l}\text { Volatilitas menggambarkan } \\
\text { tingkat risiko yang dihadapi } \\
\text { pemodal karena } \\
\text { mencerminkan fluktuasi } \\
\text { harga }\end{array}$ & $\begin{array}{l}\quad S^{2}=\frac{1}{n-1} \sum_{t=1}^{n}\left(R_{t}-\bar{R}_{t}\right)^{2} \\
\mathrm{~S}: \text { standar deviasi } \\
\mathrm{n} \text { : jumlah observasi } \\
\mathrm{R}_{\mathrm{t}} \text { : return saham i } \\
\mathrm{R}_{\mathrm{t}} \text { : rata-rata retrn saham }\end{array}$ \\
\hline $\begin{array}{l}\text { Vol.Perdagan } \\
\text { gan (Mturn) }\end{array}$ & $\begin{array}{l}\text { Volume perdagangan } \\
\text { adalah jumlah saham yang } \\
\text { diperdagangkan dalam } \\
\text { periode tertentu. Penelitian } \\
\text { ini menggunakan periode } \\
\text { bulanan }\end{array}$ & $=\frac{\text { MTurn }}{\text { saham yang diperdagangkan }}$ \\
\hline
\end{tabular}

\section{Populasi Dan Sampel}

Populasi dalam penelitian ini adalah seluruh perusahaan yang masuk dalam kelompok Index LQ45 yang ada pada Bursa Efek Indonesia (BEI) periode 2014-2016. Dengan menggunakan purposive sampling, peneliti memberikan pertimbangan melalui kriteria-kriteria sebagai prasyarat unit analisis pada penelitian ini. Kriteria-kriteria yang dimasksud dalam penelitian ini adalah:

1. Perusahaan-perusahaan yang konsisten berada di List LQ45 minimal dua tahun pada periode 2014-2016.

2. Saham dari emiten aktif diperdagangkan selama periode tahun 2014 sampai dengan 2016.

3. Ketersediaan dan kelengkapan data selama periode pengamatan 20142016.

Berdasarkan kriteria tersebut, maka terdapat 40 (emapat puluh) perusahaan. Selanjutnya data sampel dalam penelitian ini menggunakan data rata-rata dari perusahaan sampel sehingga diperoleh data sejumlah 12 bulan selama 3 tahun sebesar 36 data observasi.

\section{Metode Analisis}

Penelitian ini menggunakan analisis kuantitatif sebagai metode analisis data. Analisis kuantitatif dilakukan dengan cara mengumpulkan data yang sudah ada kemudian mengolah dan menyajikan dalam bentuk tabel, grafik dan dibuat analisis agar dapat ditarik kesimpulan sebagai dasar pengambilan keputusan (Ghozali, 2011). Teknik analisis yang digunakan dalam penelitian ini adalah model Vektor Autoregression (VAR) menggunakan software aplikasi Eviews 9.

VAR (Vector Autoregression) adalah pendekatan non-struktural (lawan dari pendekatan struktural, seperti pada persamaan simultan) yang menggambarkan hubungan yang "saling menyebabkan" (kausalistis) antar variabel dalam sistem. Metodologi VAR pertama kali 
dikemukakan oleh Sims (1980). Dalam tahap awal pengujian variabel penelitian ini menggunakan metode VAR (Vektor Autoregression) digunakan apabila data yang digunakan adalah stasioner seluruhnya pada tingkat level. Penyusunan model VAR dalam penelitian ini terdiri dari beberaapa tahapan, sebelum tahapan pengujian dan perhitungan dilakukan maka seluruh data harus disamakan dulu satuannya.

Dalam penelitian ini data diuji kestasioneritas datanya dengan menggunakan uji akar unit (unit root test) menggunakan metode Augmented Dickey Fuller (ADF). Apabila data stasioner pada tingkat level maka dilanjutkan dengan persamaan VAR biasa (unrestricted VAR) yang terdiri dari dua persamaan guna menentukan panjang lag VAR yang optimal selanjutnya dilakukan uji stabilitas model VAR dan dilanjutkan dengan uji kausalitas granger, uji kointegrasi serta pemodelan sistem VAR. Jika hasil uji ADF menunjukan hasil data yang tidak stasioner maka dalam uji kointegrasi hasil datanya bisa saling kointegrasi dan tidak saling kointegrasi. Apabila data tidak stasioner seluruhnya pada tingkat level dan saling kointegrasi maka dapat menggunakan model VECM (Vektor Error Correction Model) yang merupakan pengembangan model VAR untuk analisa lebih mendalam adanya data yang tidak stasioner. Jika data tidak stasioner seluruhnya pada tingkat level dan tidak saling kointegrasi maka dapat menggunakan model VAR dengan data bentuk differensi (VAR in difference).

\section{HASIL DAN PEMBAHASAN}

\section{Uji stasioneritas}

Dalam penelitian ini data diuji dengan menggunakan Augmented Dickey Fuller (ADF). Data yang stasioner menurut uji ADF memiliki nilai absolut yang lebih besar dari nilai kritisnya (Widarjono, 2007). Pengujian $\tau$ - nilai statistik yang diperoleh kemudian dibandingkan dengan $\mathrm{t}$ tabel nilai McKinnon Critical Value dengan syarat :

1. Jika $\tau$ - nilai statistik < dari $\mathrm{T}$ tabel McKinnon Critical Value, berarti H0 diterima dan $\mathrm{H} 1$ ditolak yang artinya data tidak stasioner.

2. Jika $\tau$ - nilai statistik > dari $\mathrm{T}$ tabel McKinnon Critical Value, berarti H0 ditolak dan $\mathrm{H} 1$ diterima yang artinya data stasioner.

Pengujian ini juga dapat didasarkan pada perbandingan antara nilai probability ADF dengan nilai signifikansi 5\% dengan syarat sebagai berikut:

1. Jika niali probability ADF $<5 \%$ $(0,05)$, berarti H0 ditolak yang artinya data stasioner

2. Jika niali probability $\mathrm{ADF}>5 \%$ $(0,05)$, berarti H0 diterima yang artinya data tidak stasioner

Hasil uji stasioneritas Augmented Dickey Fuller (ADF) yang dilakukan terhadap sampel penelitian ditunjukan pada Tabel 2.

Karena dari data variabel-variabel tersebut tidak seluruhnya stasioner pada tingkat level atau terdapat salah satu data variabel yang tidak stasioner yaitu Market Return, maka perlu dilakukan differincing data untuk menstasionerkan data-data yang belum stasioner. Hasil uji Augmented Dickey Fuller (ADF) Firs Difference dijelaskan Tabel 3.

Dilihat dari Tabel 3, melalui uji stasioneritas pada tingkat first difference bahwa nilai ADF test statistik pada Market Return, Market Turnover dan Volatilitas nilainya lebih besar dari nilai uji critical value 5\% dan nilai probablity ADF pada ke tiga variabel tersebut nilainya lebih kecil dari signifikansi 5\%. Dapat disimpulakan $\mathrm{H} 0$ ditolak yang artinya data stasioner pada tingkat first diffeence.

\section{Penentun Panjang Lag}

Penentuan lag optimal dapat ditentukan dengan menggunakan beberapa kriteria yaitu : LR (Likelihood Ratio), AIC (Akaike Information Criterion), SIC (Schwarz Information Criterion), FPE (Final Prediction Error), dan HQ (HannanQuinn Information Criterion). Berdasarkan perhitungan pada masing-masing kriteria 
yang tersedia pada program Eviews, lag optimal ditandai dengan tanda * (bintang). Kriteria pemilihan lag optimal adalah pada LR yang terbesar atau pada AIC, SC, FPE dan HQ bernilai kecil (Juanda dan Junaidi, 2012: 138). Hasil uji VAR Lag Order Selection Criteria yang menunjukan lag optimal dijelaskan Tabel 4.

Pemilihan lag optimal dalam penelitian ini menggunakan kriteris AIC dan SIC. Berdasarkan hasil uji Lag Order Selection Criteria menunjukan bahwa lag 1 adalah kelambanan yang optimal yang ditunjukan dengan nilai kriteria AIC dan SIC.

\section{Estimasi Model VAR}

Estimasi model VAR digunakan untuk menjawab rumusan dari hipotesis. Estimasi dalam VAR menggunakan jumlah lag yang telah ditentukan berdasarkan kriteria perhitungan lag optimal. Lag yang optimal diperlukan untuk menentukan dalam kerangka menangkap pengaruh dari setiap peubah lainnya dalam VAR (Juanda dan Junaidi, 2012 : 138). Dalam penelitian ini menggunakan lag 1 berdasarkan pada lag lengh criteria. Sebagai perbandingannya dapat dengan menggunakan nilai kritis tstatistik 2,03. Jika nilai t-statistik variabel mendekati 2,03 atau lebih besar 2,03 maka dikatakan signifikan. Hasil estimasi model VAR dijelaskan Tabel 5.

\section{Model persamaan yang terbentuk adalah: \\ MTURN $=\mathrm{C}+0.823635 \operatorname{MRET}(-1)+$ 0.091162 MTURN (-1) + $\mathbf{1 . 5 9 0 1 6 8}$ VOLATILITAS}

Apabila perubahan MTUR bulan lalu meningkat sebesar 1 persen, maka akan menyebabkan perubahan MTURN pada bulan ini meningkat sebesar 0.091162 persen. Selanjutnya koefisien regresi variabel MRET sebesar 0.823635 artinya apabila perubahan MRET bulan lalu meningkat sebesar 1 persen, akan menyebabkan MTURN meningkat sebesar 0.823635 persen. Apabila perubahan
VOLATILITAS bulan lalu meningkat sebesar 1 persen, akan menyebabkan perubahan MTURN bulan ini meningkat sebesar 1.590168 persen.

\section{MRET $=\mathrm{C}+\mathbf{0 . 8 8 7 6 4 9}$ MRET $(-1)$ $+\mathbf{0 . 0 5 8 3 3 2}$ MTURN (-1) -0.141303 VOLATILITAS}

Dari persamaan di atas terlihat pengaruh lag 1 Market Return (MRET) dan Market Turnover (MTURN) signifikan terhadap MRET. Sedangkan dan VOLATILITAS tidak signifikan. Apabila perubahan MRET bulan lalu meningkat sebesar 1 persen, akan menyebabkan perubahan MRET bulan ini meningkat sebesar 0.887649 persen. Apabila perubahan MTURN bulan lalu meningkat sebesar 1 persen, maka akan menyebabkan MRET bulan ini meningkat sebesar $\mathbf{0 . 0 5 8 3 3 2}$ persen. Koefisien variabel volatilitas menunjukan nilai -0.141303 , yang artinya apabila perubahan VOLATILITAS bulan lalu meningkat 1 persen, akan menyebabkan MRET bulan ini menurun sebesar 0.141303 persen.

\section{Uji Kausalitas Granger (Granger Causality)}

Uji kausalitas adalah pengujian untuk menentukan hubungan sebab akibat antara peubah dalam sistem VAR. Hubungan sebab akibat ini dapat diuji dengan menggunakan uji kausalitas granger (Juanda dan Junaidi, 2012:145). Hipotesis yang dipakai dalam uji kausalitas granger adalah :

- $\mathrm{H}_{0}$ : suatu variabel tidak menyebabkan satu variabel lainnya

- $\mathrm{H}_{1}$ : suatu variabel menyebabkan satu variabel lainnya

Jika nilai $\mathrm{F}$ statistik $>\mathrm{F}$ kritis ( $\mathrm{F}$ tabel) pada level signifikansi maka $\mathrm{H}_{0}$ ditolak, yang berarti bahwa antar satu variabel dengan satu variabel lainnya saling mempengaruhi. Hasil dari uji kausalitas granger dijelaskan Tabel 6 .

Dari hasil yang diperoleh di Tabel 6 dapat disimpulkan bahwa variabel MTURN secara statistik signifikan mempengaruhi MRET yang dibuktikan dengan nilai F- 
Statistik lebih besar dari nilai $\mathrm{F}$ tabel $(3,27)$ yang artinya $\mathrm{H} 0$ ditolak atau suatu variabel menyebabkan variabel lainnya. Sedangkan MRET secara statistik tidak signifikan mempengaruhi MTURN dibuktikan dengan nilai F-Statistik < F tabel $(3,2)$ atau $\mathrm{H} 0$ diterima, sehingga dapat disimpulkan kausalitas yang terjadi adalah kausalitas satu arah.

Tabel 2. Hasil uji stasioneritas Augmented Dickey Fuller (ADF) pada Tingkat Level

\begin{tabular}{ccccc}
\hline Variabel & ADF Test Statistic & Critical Value 5\% & Prob ADF & Ket \\
\hline MRET & -2.263341 & -2.948404 & 0.1890 & $\begin{array}{c}\text { Tidak } \\
\text { Stasioner }\end{array}$ \\
MTURN & -5.849520 & -2.948404 & 0.0000 & Stasioner \\
VOLATILITAS & -7.143035 & -2.948404 & 0.0000 & Stasioner \\
\hline
\end{tabular}

Tabel 3. Hasil uji stasioneritas Augmented Dickey Fuller (ADF) pada First Difference

\begin{tabular}{ccccc}
\hline Variabel & ADF Test Statistic & Critical Value 5\% & Prob ADF & Ket \\
\hline MRET & -8.322157 & -2.948404 & 0.0000 & Stasioner \\
MTURN & -9.696069 & -2.948404 & 0.0000 & Stasioner \\
VOLATILITAS & -6.227965 & -2.948404 & 0.0000 & Stasioner \\
\hline
\end{tabular}

Tabel 4. Hasil Uji Lag Selection

\begin{tabular}{|c|c|c|c|c|c|c|}
\hline \multicolumn{7}{|c|}{$\begin{array}{l}\text { VAR Lag Order Selection Criteria } \\
\text { Endogenous variables: MRET } \\
\text { MTURN } \\
\text { Exogenous variables: C } \\
\text { EOLATILITAS } \\
\text { Date: } 02 / 21 / 18 \text { Time: } 21: 22 \\
\text { Sample: } 136 \\
\text { Included observations: } 33 \\
\end{array}$} \\
\hline Lag & $\log L$ & LR & FPE & AIC & SC & HQ \\
\hline $\begin{array}{l}0 \\
1 \\
2 \\
3\end{array}$ & $\begin{array}{l}94.07904 \\
126.3847 \\
127.6849 \\
128.8697\end{array}$ & $\begin{array}{c}\text { NA } \\
56.77970 * \\
2.127506 \\
1.795220\end{array}$ & $\begin{array}{l}1.46 \mathrm{e}-05 \\
2.63 \mathrm{e}-06^{*} \\
3.12 \mathrm{e}-06 \\
3.74 \mathrm{e}-06\end{array}$ & $\begin{array}{l}-5.459336 \\
-7.174832 * \\
-7.011204 \\
-6.840589\end{array}$ & $\begin{array}{l}-5.277941 \\
-6.812042^{*} \\
-6.467020 \\
-6.115009\end{array}$ & $\begin{array}{l}-5.398302 \\
-7.052764 * \\
-6.828103 \\
-6.596454\end{array}$ \\
\hline \multicolumn{7}{|c|}{$\begin{array}{l}\text { * indicates lag order selected by the criterion } \\
\text { LR: sequential modified LR test statistic (each test at } 5 \% \\
\text { level) } \\
\text { FPE: Final prediction error } \\
\text { AIC: Akaike information criterion } \\
\text { SC: Schwarz information criterion } \\
\text { HO: Hannan-Quinn information criterion }\end{array}$} \\
\hline
\end{tabular}

Tabel 5. Estimasi Model VAR

\begin{tabular}{|c|c|c|}
\hline & MRET & MTURN \\
\hline MRET $(-1)$ & $\begin{array}{r}0.887649 \\
(0.12889) \\
{[6.88685]}\end{array}$ & $\begin{array}{r}0.823635 \\
(0.90448) \\
{[0.91062]}\end{array}$ \\
\hline MTURN(-1) & $\begin{array}{r}0.058332 \\
(0.02281) \\
{[2.55741]}\end{array}$ & $\begin{array}{r}0.091162 \\
(0.16006) \\
{[0.56955]}\end{array}$ \\
\hline C & $\begin{array}{r}0.007497 \\
(0.00666) \\
{[1.12645]}\end{array}$ & $\begin{array}{r}-0.047015 \\
(0.04670) \\
{[-1.00667]}\end{array}$ \\
\hline VOLATILITAS & $\begin{array}{r}-0.141303 \\
(0.06128) \\
{[-2.30577]}\end{array}$ & $\begin{array}{r}1.590168 \\
(0.43004) \\
{[3.69768]}\end{array}$ \\
\hline R-squared & 0.611344 & 0.342427 \\
\hline $\mathbf{A d j}_{\mathbf{j}} \mathbf{R}$-squared & 0.573732 & 0.278791 \\
\hline Sum sq- Resids & 0.012112 & 0.596445 \\
\hline S.E. equation & 0.019766 & 0.138709 \\
\hline F-statistic & 16.25400 & 5.381030 \\
\hline Log likelihood & 89.79309 & 21.59920 \\
\hline Akaike AIC & -4.902463 & -1.005668 \\
\hline Schwarz SC & -4.724708 & -0.827914 \\
\hline Mean dependent & 0.035461 & 0.067362 \\
\hline S.D. dependent & 0.030275 & 0.163333 \\
\hline
\end{tabular}


Tabel 6. Hasil Uji Kausalitas Granger

\begin{tabular}{|llll|}
\hline Pairwise Granger Causality Tests & & & \\
Date: $02 / 21 / 18$ Time: $23: 17$ & & & \\
Sample: 136 & & & \\
Lags: 1 & Obs & F-Statistic & Prob. \\
\hline \hline Null Hypothesis: & & & \\
\hline \hline MTURN does not Granger Cause & 35 & 5.87601 & 0.0212 \\
MRET & & 1.75755 & 0.1943 \\
MRET does not Granger Cause MTURN & & & \\
\hline \hline
\end{tabular}

\section{PEMBAHASAN}

Hipotesis pertama menduga terdapat hubungan positif antara return saham (MRET) dengan volume perdagangan (MTURN) ditolak. Namun berdasarkan hasil uji analisis yang dilakukan dengan model VAR dan Impulse Response Fumction (IRF) menunjukan hasil bahwa koefisien regresi variabel MRET sebesar 0.823635 artinya apabila perubahan MRET bulan lalu meningkat sebesar 1 persen, akan menyebabkan MTURN meningkat sebesar 0.823635 persen. Hal tersebut mengindikasikan adanya hubungan positif namun tidak signifikan karena dari hasil estimasi model VAR dimana nilai statistik $0.56955<\mathrm{t}$ statistik $(2,03)$ yang menunjukan hubungan tidak signifikan antara MRET dengan MTURN. Artinya market return yang diperoleh sebelumnya dapat mempengaruhi pergerakan market turnover dimasa mendatang namun pengaruhnya tidak terlalu besar. Hasil tersebut berbeda dengan temuan Sindhu dan Waris (2014), Statman dan Theorly (2006) bahwa return berhubungan positif signifikan dengan volume perdagangan. Berdasarkan hasil analisi yang diperoleh dapat mengidentifikasi adanya perilaku overconfidence di Bursa Efek Indonesia. Hal tersebut terjadi karena ketika suatu saham memberikan return positif kepada investor, pada saat itulah timbul keinginan dalam diri investor untuk meningkatkan perdagangan kedepannya dengan keyakinan bahwa return yang didapat akan lebih besar. Tanpa berpikir panjang layaknya investor rasional, dengan modal keyakinan yang kuat dan mengabaikan informasi pasar yang masuk, investor tersebut terus melakukan perdagangan saham sehingga meningkatkan volume perdagangan menjadi lebih tinggi.

Hipotesis kedua menduga terdapat hubungan positif antara volatilitas dengan volume perdagangan (MTURN) diterima. Berdasarkan estimasi model VAR dipeoleh hasil nilai statistik $3.69768>$ t-statistik $(2,03)$ yang artinya volatilitas secara statistik berpengaruh signifikan terhadap volume perdagangan (MTURN). Dalam estimasi model VAR koefisien regresi volatilitas sebesar 1.590168, artinya apabila perubahan Volatilitas bulan lalu meningkat sebesar 1 persen, akan menyebabkan perubahan MTURN bulan ini meningkat sebesar 1.590168 persen. Sehingga dapat disimpulkan terdapat hubungan positif signifikan antara volatilitas dengan volume perdagangan (MTURN). Hal tersebut tidak sesuai dengan teori prospek yang menyatakan bahwa seseorang dalam kondisi ketidakpastian, orang akan memilih pilihan yang menghasilkan expected utility terbesar, dimana ketika volatilitas (tingkat risiko) naik investor akan menghindari kerugian dengan mengurangi transaksinya sehngga volume perdagangan saham 
menurun. Akan tetapi bias overconfidence menyebabkan investor menjadi understimate (menaksir terlalu rendah) terhadap adanya risiko dan cenderung mengabaikan tingkat risiko sehingga membuatnya justru lebih agresif bertransaksi saham dan meningkatkan volume perdagangan. Hasil penelitian tersebut didukung oleh penelitian Shindu dan Waris (2014), Salma Zaiane (2013).

\section{PENUTUP}

\section{Simpulan}

Simpulan yang dapat diambil dari hasil pembahasan mengenai perilaku overconfidence di bursa efek Indonesia periode 2014 sampai 2016 yang dilihat dari hubungan market return dengan market turnover dan volatilitas adalah sebagai berikut

Dari hasil penelitian dan pembahasan membuktikan bahwa $\mathrm{H} 1$ : Terdapat hubungan positif antara Maket Return dengan Market Turover, ditolak dan $\mathrm{H} 2$ : Terdapat hubungan positif signifikan antara Volatilitas dengan Market Turnover, diterima.

Dari pembahasan analisis data dapat ditarik kesimpulan bahwa Investor di Bursa Efek Indonesia mengalami overconfidence yang mana ditunjukan oleh sikap investor dalam menanggapi guncangan (shock) market return, volatilitas (tingkat risiko) dan market turnover. Walaupun demikian, dampak overconfidence yang terjadi relatif kecil dan tidak terlalu mempengaruhi bursa efek. Maka investor dalam melakukan investasi seharusnya tidak terpaku pada perolehan return masa lalunya dengan harapan mendapatkan return yang sama bahkan yang lebih tinggi dimasa akan datang serta melakukan analisis ulang lagi dalam pengambilan keputusan investasi di kemudian hari dengan melakukan riset seperti mempelajari laporan keuangan perusahaan, kinerja perusahaan, track record atau portofolio dan informasi mengenai keadaan perekonomian yang dipublikasikan serta investor disarankan harus tetap mempertimbangkan volatilitas (tingkat risiko) yang diperoleh sebelum bertransaksi agar dapat memperoleh keuntungan. Hal tersebut dilakukan agar investasi yang dilakukan dapat memberikan kepuasan yang optimal.

\section{Saran}

Dari kesimpulan dan pembahasan sebelumnya, terdapat beberapa saran yang diajukan dalam penelitian ini, diantaranya adalah:

Untuk penelitian yang akan datang disarankan untuk mencari ruang lingkup populasi yang berbeda dan lebih luas dari populas dalam penelitian ini, Pengambilan populasi dalam penelitian ini hanya dari perusahaan yang masuk ke dalam Index LQ45 periode 2014-2016. Hal tersebut sangat membatasai jumlah perusahaan yang bisa masuk sebagai sampel penelitian. Penelitian selanjutnya agar menggunkan seluruh perusahaan yang terdaftar di Bursa Efek Indonesia sebagai populasinya, sehingga perusahaan yang memiliki market capital kecil tetapi likuid juga terwakili serta menambah rentang waktu penelitian menjadi 5 tahun atau 10 tahun.

Untuk penelitian selanjutnya terkait perilaku overconfidence, peneliti menyarankan untuk menggunakan data mingguan bahkan harian agar dapat memberikan gambaran yang lebik konkrit mengenai hubungan antar variabel yang digunakan. Apalagi jika model VAR tetap digunakan, akan lebih baik jika pengujiannya menggunakan data yang lebih banyak.

\section{DAFTAR PUSTAKA}

Abaoub \& Zaiane. (2009). Investor Overconfidence and Trading Volume; The Case of An Emergent Market. International Review of Business Research Papers, 5(2), 213-222. 
Anoraga, P., \& Pakarti, P. (2006). Pengantar Pasar Modal, cet V. Jakarta: PT Rineka Cipta.

Budi, B. (2010). Behavioral Finance, udah Waktunya. Jakarta: PT Evolitera.

Cristianti \& Mahastanti. (2011). FaktorFaktor yang Dipertimbangkan Investor dalam Melakukan Investasi. Journal Manajemen dan Terapan. 4(3), 37-51.

Doddy, A.. (2012). Ekonometrika Esensi dan Aplikasi dengan menggunakan Eviews. Jakarta: Erlangga.

Fischhoff, B., Solvic, P., \& Lischtenstein, S. (1997). Knowing With Certainly : The appropriateness of Extreme Confidence. Journal of Experimental Psikology Human Preseption and Performance. 3(4), 552.

Gervais \& Odean. (2001). Learning to be Overconfidence. Review of Finansial Studies 14, 1-27.

Griffin, M. Etc. (2003). The Dynamics of Institutional and Individual Trading. The Journal of Finance, 6.

Hartono, J. (2014). Teori Portofolio dan Analisis Investasi Edisi Kesepuluh. Yogyakarta: BPFE Yogyakarta.

Juanda, B. \& Junaidi. (2012). Ekonometrika Deret Waktu Teori dan Aplikasi. Bogor: IPB Press.

Mahyus, E. (2014). Ekonometrika Dasar untuk Penelitian Di bidang Ekonomi, Sosial dan Bisnis. Jakarta: Mitra Wacana Media.

Marwan, A. (2013). Keuangan Keperilakuan. Yogyakarta: BPFE Yogyakarta.

Maulana, R. \& Yatini. (2013). Analisis Pergerakan Return Saham dan Volume Perdagangan sebelum dan Sesudah Pengumuman Laporan Keuangan. JMA, 18(2), 88.
Napitupulu, V. \& Syahyunan. (2012). Pengaruh Return Saham, Volume Perdagangan Dan Volatilitas Harga Saham Terhadap Bid Ask Spread Pada Perusahaan Yang Melakukan Stock Split Di Bursa Efek Indonesia. Jurnal Departemen FE USU, Sumatra Utara.

Nugraha, N. F. \& Kartini. (2015). Pengaruh Ilusion of Control, Overconfidence dan Emotion terhadap Pengambilan Keputusan Investasi pada Investor di Yogyakarta. Jurnal Inovasi dan Kewirausahaan, 4(2), 114-122.

Pompian, M. (2006). Behavioral Finance and Wealth Management : How to Built Optimal Portofolios that Account for Investor Biases. New Jersey: John Wiley and Sons,Inc. Diakses November 2017.

Santoso, S. (2014). Statistik Multivariate Edisi Revisi. Jakarta: PT Elex Media Komputindo.

Shefrin. (2000). Beyond Greed and Fear: Understanding Behavioral Finance and the Psychology of Investing.

Shindu, M. I. \& Waris, F. (2014). Overconfidence and Turnover: Evidence from Karachi Stock Exchange. European Journal of Business and Management, 6(7), 128135.

Statman, M. \& Thorley, S. (2006). Investor Overconfidence and Trading Volume. The Review of Financial Studies, 19(4). Doi :10.1093/rfs/hhj032.

Suad, H. (1998). Dasar - Dasar Portofolio dan Analisis Sekuritas Edisi Kedua. Yogyakarta: UPP-AMP YKPN

Sugiyono. (2016). Metode Penelitian Kuantitatif , Kualitatif dan Kombinasi (Mixed Methods). Bandung: Alfabeta.

Sunariyah. (2011). Pengantar Pengetahuan Pasar Modal Edisi Keenam. Yogyakarta: UPP STIM YKPN. 
Sutrisno. (2000). Manajemen Keuangan. Yogyakarta: Ekonosia.

Victor, R. \& Helen, S.K. (2000). What is Behavioral Finance? Bussines, Education and Technology Journal, 19.

Zaiane, S. (2013). Overconfidence, Trading Volume and The Disposition Effect: Evidence from The Shenzhen Stock Market of China. Issues in Bussiness Management and Economics, 1(7), 163-175.

Tandellin, E. (2010). Portofolio dan Investasi Teori dan Aplikasi Edisi Pertama.Yogyakarta : Kanisius IKAPI.

Tim Studi Volatilitas Pasar Modal Indonesia dan Perekonomian Dunia. (2011). Volatilitas Pasar Modal Indonesia dan Perekonomian Dunia. Kementrian Keuangan Republik Indonesia.

Widarjono, A. (2007). Ekonometrika Teori dan Aplikasi untuk Ekonomi dan Bisnis Edisi Kedua. Yogyakarta: Ekonisia Fakultas Ekonomi UII.

Wiryaningtyas, D. P. (2016). Behavioral Finance dalam Pengambilan

Keputusan. Prosiding Seminar Nasional UNEJ, 339-344.

Undang- Undang No 8 Tahun 1995 tentang Pasar Modal.

www.idx.co.id

www.sahamok.com

www.yahoofinance.com 